\title{
Benefits Brought by the Abundance and Importance of Forest Fruits from Bistrita-Nasaud County
}

\author{
Ciprian TUDOR*, Lucian DINCĂ, Cristinel CONSTANDACHE \\ 'Marin Drăcea' National Institute for Research and Development in Forestry \\ *corresponding author: cipriantudor95@yahoo.com
}

BulletinUASVM Horticulture 77(1) / 2020

Print ISSN 1843-5254, Electronic ISSN 1843-5394

DOI:10.15835/buasvmcn-hort: 2019.0024

\begin{abstract}
Non-woody forest products (NWFPs) represent an important forest resource which can be exploited, becoming in this way, an important economic role in human societies. In addition, NWFPs are used both in households and as commercial products for human well-being. Due to the fact that Romania has a wide variety of relief forms, numerous NWFPs can be found on her territory, the most important ones being the forest fruits. Their benefits come especially from their chemical composition, because of the richness in vitamins and antioxidant properties, being used in alimentation, medicine and the cosmetic industry. On the other hand, their importance is gained by the social and economic impacts, most of them being positive. The paper exposes the most representative forest fruits from Bistrita-Năsăud County which were analysed by using an analytical hierarchy process, being a multicriteria method in decision making. Based on this process, forest fruits were classified by 19 well-established criteria.
\end{abstract}

Keywords: analytical hierarchy process, forest fruits, market potential, multi-criteria, non-woody forest products

\section{Introduction}

FAO estimates that approximately $80 \%$ of populations from developing countries use NWFPs in food and medical industries.

Our department has launched in 1991 a priority program for the development and promotion of non-timber products. These NWFPs include forest fruits, medicinal plants, resins, edible mushrooms, seeds, hunt etc. NWFPs are utilised in medical purposes, in the food and cosmetics industry as well as in constructions (Janse and Ottitsch, 2005).

The consumption of forest fruits has a significant importance due to their flavonoid content, which is appreciated for its antioxidant properties, contributing to the decrease of cardiovascular diseases (Knekt et al., 1997, Kanodia et al., 2011, Milivojević et al., 2011).

The definition proposed by FAO describes non-woody forest products (NWFP) as "products of biological origin other than wood derived from forests, other wooded land and trees outside forests". There are excluded from definition the raw materials (charcoal, chips, fuelwood) and products that were collected in agricultural or agroforestry systems, including products as rubber, gum arabic, resin, latex, Christmas trees and so on (FAO, 2015). For the harvesting activity of forest fruits it is important to follow two main essential aspects: to fulfill the sustainable principle of forest resources and not to affect the biodiversity of the environment (Vasile et al., 2016). 


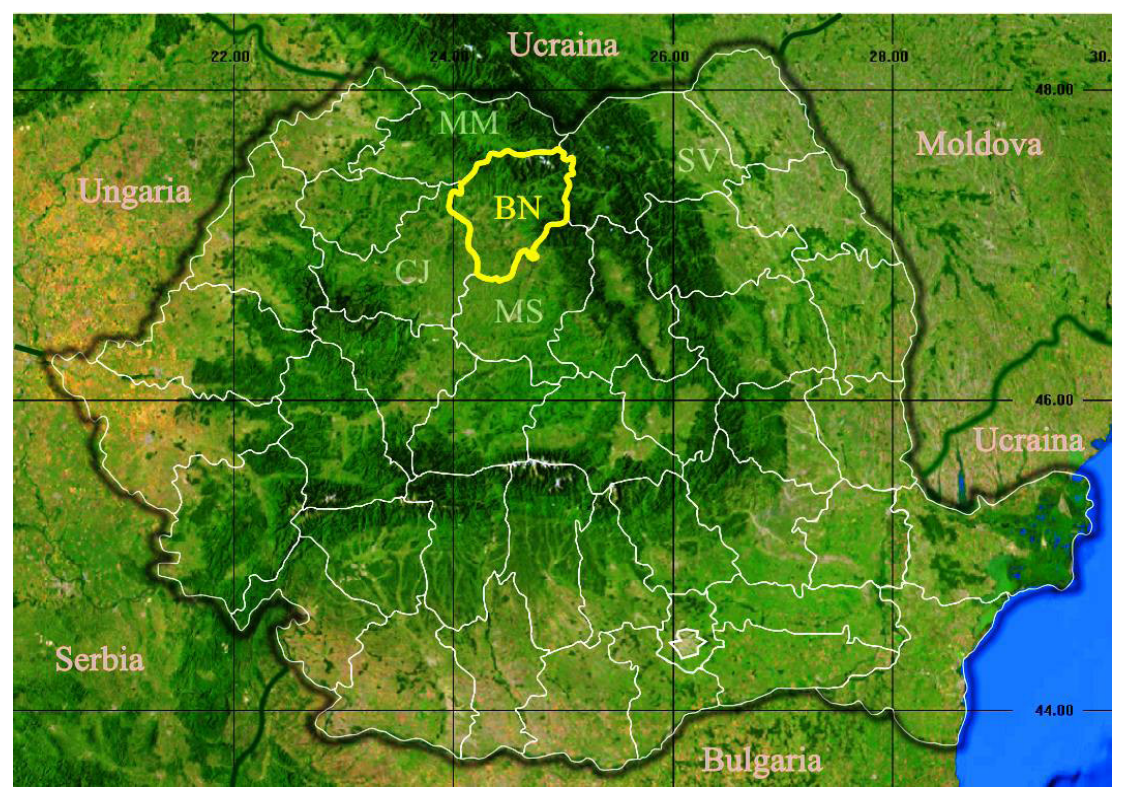

Figure 1. Location of Bistrita-Năsăud County (https://www.wikipedia.org)

During the past decades, the role of the forest has changed in Europe. Besides wood, its principal source, non-timber resources have become of interest. According to the Food and Agriculture Organization (FAO), the term which characterizes these resources is "non-timber forest products" (NWFPs). Furthermore, from economic point of view, through the STARTREE project (www.startree.eu), using UN Comtrade database, NWFP estimates the values and volumes in international trade. There were examined cork, tannins, mushrooms, nuts, berries, foliage and honey. Wild harvested NWFPs amounted 4.69 billion USD, from the total sum of 12 billion USD which was registered at global trade (Prokofieva et al., 2017). The Romanian Forest Code (Law 46/2008), according to Article 58, paragraph (3) specifies that "non-woody forest products include fauna of hunting interest, fish from mountain waters, forest fruits, forest seeds, truffles and edible mushrooms, medicinal and aromatic plants, resin, and so on" (Enescu et al., 2018). However, when planning the forest management process it's important to take into account the increase in consumption and popularity of NWFPs, and also their harvesting and exploitation, both being important aspects (Blaga et al., 2019).

The scope of the present paper is to identify and to extract form the abundance of non-woody forest products, only the most important forest fruits from Bistrita-Năsăud County, Romania. From a geographical point of view, this County is situated in the North-East part of Transylvania's Plateau, being crossed by the river Bistrita. Its estimated surface reaches 5.355 square kilometres. According to INSSE the forest surface has occupied 187837 hectares in 2017, with a predominance of hardwood forests which occupy 106320 hectares and softwoods, with approximately 81517 hectares. The regenerated surface in 2017 summed up a total of 1336 hectares (http://www. insse.ro).

The following forest fruits can be found in Bistrita-Năsăud County: roseberries (Rosa canina L.), blackberries (Rubus hirtus W. et K.), blueberries (Vaccinium myrtillus L.), blackthorns (Prunus spinosa L.), hawthorns (Crataegus monogyna L.), wild apples (Malus sylvestris L.), blackcurrant (Ribes nigrum L.), wild strawberries (Fragaria vesca $\mathrm{L}$.) and others.

\section{Material and methods}

The Bistrita-Nasaud Directorate is a unit included in the National Forest Administration, which administrates $14 \%$ of the total surface of Bistrita-NasaudCounty, the remaining of $86 \%$ being administrated by other accredited silvicultural bodies. In compliance with the evidences in 2018, the managed total surface was of 27.691 hectares, from which 12.315 hectares represent forest 
fund of state property, while the other 15.376 hectares were the property of other units such as localities, physical persons and so on. One of the traditional activities of the National Forest Administration is represented by the valorification of the non-woody forest products. Among these, the forest fruits are the most important under the quantitative and valoric aspect. Annually, the National Forest Administration offers and sells over 3000 tons of fruits, most of them being from the spontaneous flora of Romania and can be certificated as ecological agroalimentary products. The main forest fruits promoted by the National Forest Administation including here Bistrita-Nasaud Directorate, which are valorified are: blueberries, raspberries, blackberries, sea buckthorn, roseberries, blackthorns, hawthorns and so on offering to customers the special taste of forest fruits from Carpathians of Romania.

Furthermore, for enhancing the profit, the Bistrita-Nasaud Directorate organizes auctions for other non-woody forest products, such as edible mushrooms (Boletus edulis, Chantarellus cibarius, Tuber sp., and so on) and also medicinal plants being harvested from the spontaneous flora. As basic materials, there were used different reports of the economic situation of Bistrita-Nasaud Directorate, relevant documents and also some projects implemented in the annual process of valorification. For the present report, as method, it was used an AHP (The Analytical Hierarchy Process), for estimating and evaluating the potential of forest fruits. This kind of analysis was developed in 2008, by the expert Thomas Saaty, it is based on multiple criteria, being important in decision making (Saaty, 2008). This method is a structured technique for organizing and analyzing complex decisions, based on mathematics and psychology. AHP helps decision makers find one that best suits their goal and their understanding of the problem. It comprises few steps as follows: i) Decompose the decision problem into a hierarchy of more easily comprehended sub-problems, ii) Evaluate the elements of hierarchy by comparing them to each other two (pairwise comparison) at a time, iii) Convert these evaluations to numerical values that can be processed and compared over the entire range of the problem and iv) Calculate the numerical priorities for each of the decision alternatives.
In our case, the steps which were followed to bring the results for analysis include the 19-well established multi-criteria such as: 1) harvesting period, 2) harvested quantity/ worker/8 hours, 3) harvesting cost, 4) knowledge for harvesting, 5) tools needed for harvesting, 6) complexity of the harvesting process, 7) development of the harvesting process, 8) knowledge for recognition, 9) distribution range, 10) biotic threats, 11) abiotic threats, 12) perishability, 13) market potential, 14) market demand, 15) "celebrity" of the product on market, 16) the price of the raw product, 17) the price of the derived product, 18) portfolio of derived products and 19) Transport (harvesting storage centre). The used scale for evaluating the criteria is constituted of absolute numbers between the interval 1 to 8 . Once the alternatives were fixed, the criteria must be attributed to the available alternatives that suits best for the analyzed part. Also, for estimating the sensivity of the forest fruits involved in the process, the AHP uses special technique by the Expert Choice Desktop software, which is adapted for mathematical calculations and for making graphics for all the alternatives involved. These criteria have also been used in other similar studies from different counties such as: Maramures (Enescu et al., 2017), Bihor (TimisGânsac et al., 2018), Gorj (Vechiu et al., 2018), Prahova (Enescu et al., 2018), Timis (Enescu et al., 2018).

\section{Results and discussions}

Table 1 shows the relationship between berries and the attributed criteria, and also the potential alternatives established which were taken into consideration for analysing the most important forest fruits from Bistrita-Năsăud County. Based on this analytical hierarchy process (AHP), the most popular and requested forest fruits are roseberries (Rosa canina), blackberries (Rubus hirtus), blueberries (Vaccinium myrtillus), blackthorns (Prunus spinosa), hawthorns (Crataegus monogyna), wild apples (Malus sylvestris), black currants (Ribes nigrum) and wild strawberries (Fragaria vesca). It can be observed that the best ranking are the blueberries, reaching the maximum number of alternatives given for the differentcriteriasuchastoolsneededforharvesting, harvesting cost, market potential, market demand, portfolio of derived products and transport. Also, wild strawberries (Fragaria vesca) registered a 
Table 1. AHP-The number of alternatives reached by berries for each criterion (1-19)

\begin{tabular}{|c|c|c|c|c|c|c|c|c|c|}
\hline \multirow{2}{*}{\multicolumn{2}{|c|}{ Criterion }} & \multicolumn{8}{|c|}{ Berries } \\
\hline & & $\begin{array}{c}\text { Rosa } \\
\text { canina }\end{array}$ & $\begin{array}{l}\text { Rubus } \\
\text { hirtus }\end{array}$ & $\begin{array}{l}\text { Vaccinium } \\
\text { myrtillus }\end{array}$ & $\begin{array}{l}\text { Prunus } \\
\text { spinosa }\end{array}$ & $\begin{array}{l}\text { Crataegus } \\
\text { monogyna }\end{array}$ & $\begin{array}{l}\text { Malus } \\
\text { sylvestris }\end{array}$ & $\begin{array}{l}\text { Ribes } \\
\text { nigrum }\end{array}$ & $\begin{array}{l}\text { Fragaria } \\
\text { vesca }\end{array}$ \\
\hline 1 & Harvesting period & 8 & 5 & 2 & 4 & 7 & 6 & 3 & 1 \\
\hline 2 & $\begin{array}{c}\text { Harvested quantity/ } \\
\text { worker } 8 \text { hours }\end{array}$ & 7 & 2 & 3 & 5 & 6 & 8 & 4 & 1 \\
\hline 3 & Harvesting cost & 5 & 2 & 8 & 4 & 6 & 7 & 3 & 1 \\
\hline 4 & Knowledge for harvesting & 6 & 2 & 7 & 4 & 8 & 3 & 5 & 1 \\
\hline 5 & $\begin{array}{l}\text { Tools needed for } \\
\text { harvesting }\end{array}$ & 5 & 2 & 8 & 4 & 6 & 7 & 3 & 1 \\
\hline 6 & $\begin{array}{l}\text { Complexity of harvesting } \\
\text { process } \\
\end{array}$ & 6 & 2 & 7 & 4 & 8 & 5 & 3 & 1 \\
\hline 7 & $\begin{array}{l}\text { Development of harvesting } \\
\text { process }\end{array}$ & 5 & 1 & 7 & 4 & 6 & 8 & 3 & 2 \\
\hline 8 & Knowledge for recognition & 5 & 1 & 4 & 8 & 6 & 3 & 7 & 2 \\
\hline 9 & Distribution range & 8 & 6 & 3 & 2 & 7 & 4 & 1 & 5 \\
\hline 10 & Biotic threats & 2 & 7 & 3 & 1 & 6 & 8 & 5 & 4 \\
\hline 11 & Abiotic threats & 3 & 6 & 7 & 2 & 1 & 5 & 4 & 8 \\
\hline 12 & Perishability & 1 & 7 & 6 & 4 & 3 & 2 & 5 & 8 \\
\hline 13 & Market potential & 4 & 7 & 8 & 1 & 5 & 3 & 2 & 6 \\
\hline 14 & Market demand & 5 & 6 & 8 & 1 & 4 & 3 & 2 & 7 \\
\hline 15 & $\begin{array}{l}\text { "Celebrity" of the product } \\
\text { on market }\end{array}$ & 5 & 7 & 8 & 1 & 4 & 3 & 2 & 6 \\
\hline 16 & Price of raw product & 4 & 6 & 7 & 2 & 5 & 1 & 3 & 8 \\
\hline 17 & $\begin{array}{l}\text { Price of the derived } \\
\text { products }\end{array}$ & 5 & 6 & 7 & 1 & 3 & 2 & 4 & 8 \\
\hline 18 & $\begin{array}{l}\text { Portfolio of derived } \\
\text { products }\end{array}$ & 5 & 7 & 8 & 2 & 3 & 1 & 4 & 6 \\
\hline 19 & $\begin{array}{c}\text { Transport (harvesting - } \\
\text { storage center) }\end{array}$ & 4 & 5 & 8 & 2 & 3 & 4 & 6 & 7 \\
\hline
\end{tabular}

maximum number of alternatives (8) in abiotic threats, perishability, the price of raw product and the price of the derived products (Fig.2) being the sign that this fruit has a quiet sensibility in terms of conserving or protecting, being exposed to the natural diseases. The positive aspect is that wild strawberries have a lot of alternatives in market demand, for satisfying the taste and wellbeing of the costumers. In the case of hawthorns (Crataegus monogyna), there are a lot of alternatives in the sense of knowledge for harvesting. This requires a good understanding how to harvest these fruits to avoid the depreciation. The harvested quantity of roseberries, hawthorns and wild apples within 8 hours is larger in comparison with blackberries, blueberries, blackthorns, black currants and wild strawberries. On the other hand, wild strawberries and blackberries are the most perishable forest fruits. Roseberries and hawthorns have a wide distribution range in this county, being well spreaded in the entire region.
The most appreciated forest fruits are Vaccinium myrtillus L., Fragaria vesca L. and Crataegus monogyna Jack. as observed from Figure 3. Vaccinium myrtillus L. is a low-stem thick and leafy shrub, with a green stem that can reach 30 $60 \mathrm{~cm}$ and angular branches. The leaves are shortpetiolated, small, oval, denticulate (creased on the edge) and green on both sides. As such, they have antibacterial properties, favorably modifying the intestinal and antidiuretic pathogenic flora. The flowers are red, white or pinkish green with bellshaped thin petals (1-2 in the leaf axilla). It usually blooms in May-June.

Fragaria vesca L. is a perennial diploid species that can reach $15-30 \mathrm{~cm}$ in height. The flowers are white and bisexual while the fruits are fleshy, red and very aromatic (Albani et al., 2004, Oosumi et al., 2006) originally from West Ural Mountains it has expended on the entire Globe. Strawberries are rich in vitamin $\mathrm{C}, \mathrm{A}$ and $\mathrm{B} 2$ and contain mineral salts, calcium, magnesium, iron and phosphorus 


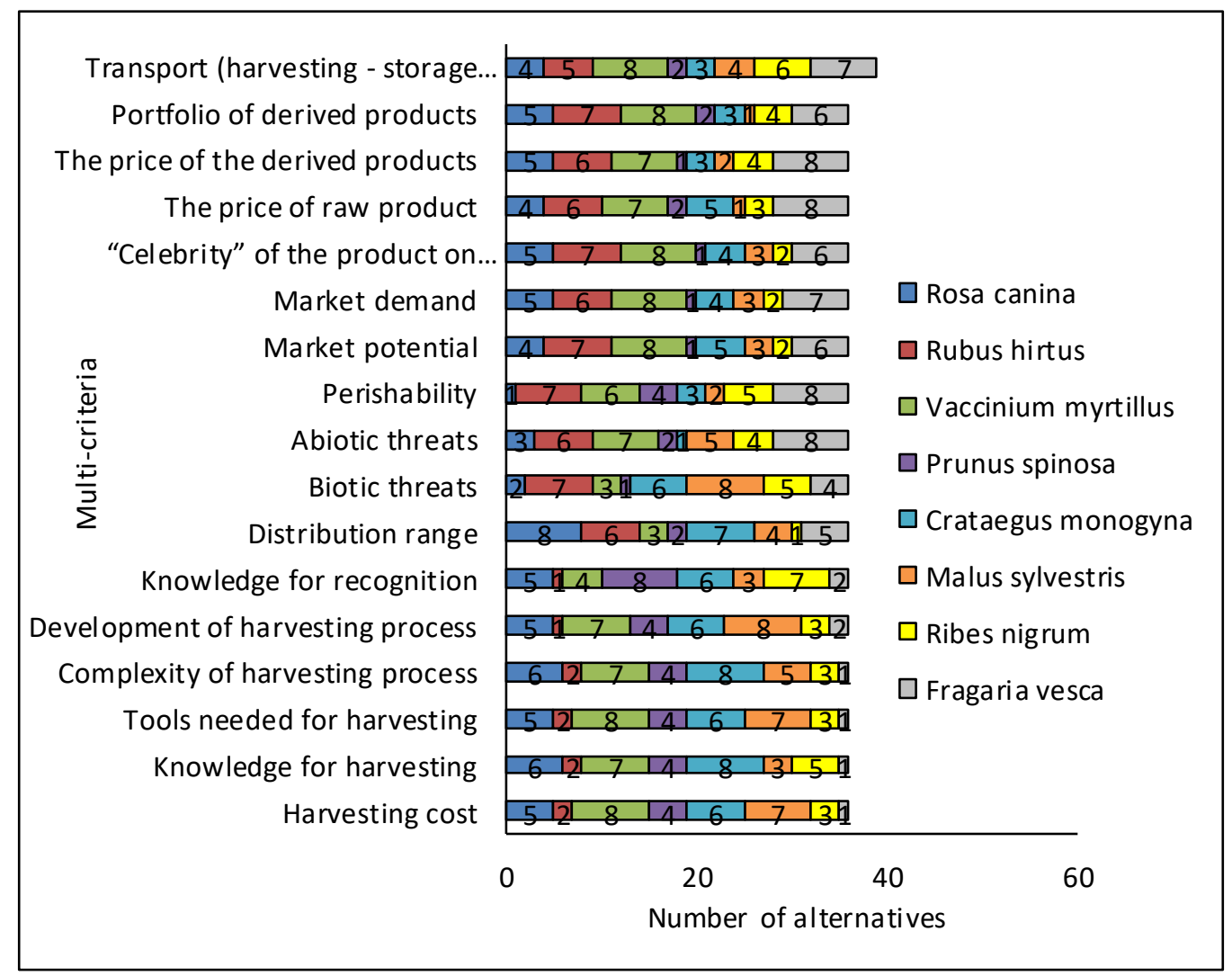

Figure 2. Ranking of alternatives

(Hummer et al., 2011, Kanodia et al., 2011, DyduchSiemińska et al., 2015). Strawberries are also used in medicine for treating intestinal diseases, tuberculosis, hypertension, asthenia, rheumatism, kidney stones, and for cleansing the body of toxins (Dias et al., 2016).

Crataegus monogyna Jack. is a shrub (2-6 m) of the Rosaceae family, with white flowers and red fruits that have a characteristic smell and bitter taste. Fruit extracts are primarily used to ameliorate disorders related to nervous and cardiac problems. Hawthorn tea has an unpleasant odour and a breeze, but it can be flavoured with lemon or other extracts. In Figure 3 it is illustrated the diagram of the most popular species through the Expert Choice Desktop software (v. 11.5.1683). From this diagram, we can observe that the most demanded from the forest fruits are blueberries, wild strawberries and hawthorns taking into consideration the high numbers of alternatives which are involved in making decisions.

There are plenty of studies related to the important values of non-woody forest products in different regions of Romania. Pocol et al., (2013) specifies in her article that in Bistrita-Nasaud County in some small rural communities it was confirmed the existence of forest resources which contribute to their development: forest fruits, handicraft products and traditional foods. In 2012, significant quantities of forest fruits were collected in concordance with the data attained by Bistrita Forestry Department, mainly exported, the profit rate reaching $15 \%$. The quantity of blueberries reached 32 tones, which was the most significant ass compared with the quantities of cranberries ( 6 tones), sea buckthorns ( 5 tones), roseberries (4 tones), raspberries ( 3 tones) and hawthorns (1 tone) (Pocol et al., 2013). For example, in Prahova County, the selected NWFPs besides fruits, consisted in mushrooms (honey fungus), medicinal plant wild garlic (Allium ursinum L.) and some of animal origin such as European roe-deer (Capreolus capreolus L.) and pheasant (Phasianus colchicus L.). Regarding the results of this analytic hierarchy process (AHP), it is shown that the highest potential of NWFPs was occupied by the roe deer, raspberry and pheasant (Enescu et al., 2018). Another example is in Bacau 


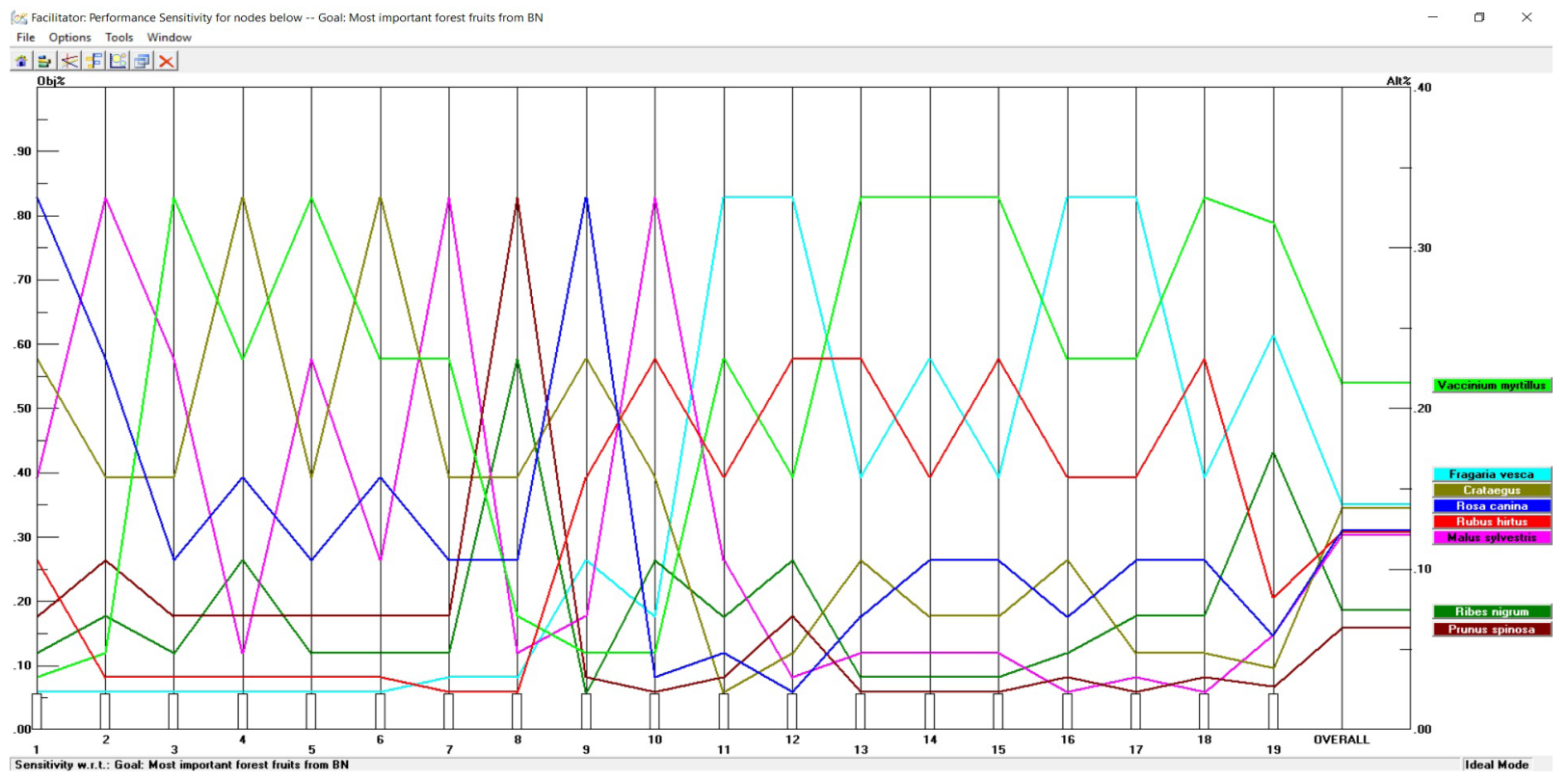

Figure 3. Diagram of the most popular forest fruits

County, where the AHP was implemented for other non-woody forest products. According to the results from Timis County obtained by Enescu et al., (2018), the most representative non-woody forest product was from the mushrooms class, the Boletus genus, which is recognized in the entire Europe for the specific and delicious taste. The most important non-woody forest products from Bacau County, based on the AHP results, were truffles and penny bun, while the least important ones were coniferous foliage and common nettle (Blaga et al., 2019).

\section{Conclusions}

The NWFPs have an important economic and social role, being a renewable resource from the forest. Bistrita-Năsăud County has a wide distribution range of forest fruits on its territory. With thehelpof theanalyticalhierarchybased on the criteria taken into account, the most representative forest fruits from this region are: blueberries, wild strawberries, hawthorns, blackberries and blackthorns. Based on this analytical hierarchy process (AHP), the most popular, sought and demanded forest fruits are roseberries (Rosa canina), blackberries (Rubus hirtus), blueberries (Vaccinium myrtillus), blackthorns (Prunus spinosa), hawthorns (Crataegus monogyna), wild apples (Malus sylvestris), black currants (Ribes nigrum) and wild strawberries (Fragaria vesca).
Most of them have a high potential in the market zone, being plenty alternatives which bring important economic benefits. The best ranked fruits, based on the AHP, were wild strawberries, blueberries and blackberries. In Bistrita-Nasaud County, forest fruits meet the necessary conditions for growth and development because the region presents different relief forms which comply with the ecological requirements of the species. As such, specialists should take into account the areas populated with all these species and to try different methods for conserving and extending them.

Acknowledgements: The authors would like to thank Mr. Cristian Mihai Enescu (Faculty of Agriculture Bucharest) for his support in analysing the data.

\section{References}

1. Albani MC, Battey NH, Wilkinson MJ (2004). The development of ISSR-derived SCAR markers around the SEASONAL FLOWERING LOCUS (SFL) in Fragaria vesca. Theoretical and applied genetics, 109(3): 571-579.

2. Blaga T, Plesca IM, Dincă L (2019). Selecting the most promising non-wood forest products for Bacău County by using the analytical Hierarchy Process. Studies and Researches, 28(1): 29-33.

3. Dias MI, Barros L, Morales P, Cámara M, Alves MJ, Oliveira MBP, Ferreira IC (2016). Wild Fragaria vesca L. fruits: a rich source of bioactive phytochemicals. Food \& function, 7(11): 4523-4532. 
4. Dyduch-Siemińska M, Najda A, Dyduch J, Gantner M, Klimek K (2015). The content of secondary metabolites and antioxidant activity of wild strawberry fruit (Fragaria vesca L.). Journal of Analytical Methods in Chemistry, 8.

5. Enescu CM, Dincă L, Vasile D (2017). Importance of nonwood forest products for Maramures County. Forestry and Cinegetics Magazine, 40: 92-97.

6. Enescu CM, Dincă L, Crisan V (2018). The most important non-wood forest products from Prahova County. Forestry Magazine, 1: 45-51.

7. Enescu CM, Dincă L, Cântar I (2018). Which are the most common non-wood forest products in Timis County? Research Journal of Agricultural Science, 50(1): 51-56.

8. FAO (2015). Terms and definitions. Forest Resource Assessment Working paper 180. Rome.

9. Hummer K, Bassil N, Njuguna W (2011). Fragaria. Wild Crop Relatives: Genomic and Breeding. Resources, 17-44.

10. Janse G, Ottitsch A (2005). Factors influencing the role of non-wood forest products and services.Forest Policy and Economics, 7(3): 309-319.

11. Kanodia L, Borgohain M, Das S (2011). Effect of fruit extract of Fragaria vesca L. on experimentally induced inflammatory bowel disease in albino rats. Indian journal of pharmacology, 43(1): 18-21.

12. Knekt $P$, Järvinen $R$, Seppänen R, Heliövaara M, Teppo L, Pukkala E, Aromaa A, (1997). Dietary flavonoids and the risk of lung cancer and other malignant neoplasms. American journal of epidemiology, 146(3): 223-230.

13. Milivojević J, Maksimović V, Nikolić M, Bogdanović J, Maletić R, Milatović D (2011). Chemicaland antioxidant properties of cultivated and wild Fragaria and Rubus berries. Journal of Food Quality, 34(1): 1-9.
14. Oosumi T, Gruszewski HA, Blischak LA, Baxter AJ, Wadl PA, Shuman JL, Shulaev V (2006). High-efficiency transformation of the diploid strawberry (Fragaria vesca) for functional genomics. Planta, 223(6): 1219-1230.

15. Pocol BC, Teselios MC, Burcea M (2013). The valorization of forest fruits in Bistrita Năsăud -A possible business in social economy sector. Agricutural Management Faculty, Scientific Works, 15(1): 248-251.

16. Prokofieva I, Lovric M, Pettenella D, Weiß G, Wolfslehner B, Wong J (2017). What is the potential contribution of non-wood forest products to the European forest-based bioeconomy?. Towards a sustainable European forestbased bioeconomy, 132 .

17. Saaty TL (2008). Decision making with the analytic hierarchy process. International Journal of Services Sciences, 1(1): 83-98.

18. Timis GV, Enescu CM, Dincă L, Onet A (2018) . The management of nonwood forest products in Bihor county. Natural Resources and Soustainable Development, 8(1): 27-34.

19. Vasile D, Dincă L, Voiculescu I (2016). Wild berries collected in 2016 from national forest fund managed by RNP Romsilva. Forestry and Cinegetics Magazine, 38: 7275.

20. Vechiu E, Dincă L, Enescu CM (2018). Which are the most important forest fruits from Gorj county? Forestry and Cinegetics Magazine, 42: 89-93.

21. https://www.cabi.org (Accessed February 6, 2019)

22. http://www.fao.org (Accessed February, 5, 2019)

23. http://www.star-tree.eu/

24. http://statistici.insse.ro (Accessed February 1, 2019)

25. https://www.wikipedia.org/ 